\title{
Rahvatraditsiooni kasutusvõimalustest talurahva ajaloo uurimisel ${ }^{1}$
}

\begin{abstract}
Ülle Tarkiainen
Teesid: Artiklis vaadeldakse, kuidas aitab ajaloolise traditsiooni tundmine uurida agraar- ja asustusajalugu, eriti viie kitsama teema puhul, mis puudutavad piiritähiseid, külade teket, talude maakasutust, pärimist ja kerjuseid. Ajaloolastele on raskusi valmistanud pärimuse dateerimine, samuti selle usaldusväärsus. Seoses mikroajaloo esiletõusuga on üha rohkem hakatud tähelepanu pöörama sellele, mida inimesed mõtlesid, ja sellele on sageli raske leida vastuseid kirjalikest allikatest. Artiklis vaatluse alla võetud pärimus on tihedalt seotud külaühiskonnaga, ja selles ilmnevad eelkõige talupoegade argieluga seotud arusaamad, mida arhiiviallikad valgustavad enamasti hoopis teisest vaatenurgast. Analüüsi tulemusel on jõutud järeldusele, ei kõige paremaid tulemusi annab ajaloolise traditsiooni arvessevõtmine suhteliselt hilisel ajal, 19. sajandi teisest poolest alates toimunud sündmuste puhul ja olukorras, kus ruumilised suhted ei ole märgatavalt muutunud. Varasemat pärimust on keerulisem kasutada, kuid seegi võimaldab näha rahva suhtumist, mis annab rahva poolt seletatud nähtustele hinge. Otse loomulikult ei kajastu arhiivimaterjalides talupoegade mõttemaailmas peituvad põhjused. Just seetõttu annab rahvapärimuse kasutamine asustus- ja agraarajaloo uurimisel olulise lisa, mis täiendab ratsionaalset pilti toimunud sündmustest ja protsessidest ning võimaldab avada toimunu sügavamaid tagamaid.
\end{abstract}

Märksõnad: agraarajalugu, asustusajalugu, mikroajalugu, minevikust jutustamine, pärimuslik ajalugu

\section{Sissejuhatus}

Ajalooteadus uurib kirjalikke allikaid, mis on Euroopas olemas juba antiikajast, kuid Eesti ala kohta alles keskajast alates. Lisaks nendele on säilinud ka rikkalik pärimus, mis on rahva suust üles kirjutatud enamasti alates 19. sajandi lõpust. Ajaloolaste silmis on rahvatraditsiooni kasutamisega seotud siiski mitmed probleemid. Esimene neist puudutab dateerimist. Ajaloolasele on tähtis kronoloogia: ajas hiljem toimunud sündmus ei saa olla varem toimunud sündmuse põhjus või seda mõjutanud tegur. Kuigi rahvaluule kogumisel on enamasti 
kirja pandud, kus ja millal on see üles kirjutatud ning kellelt, ei võimalda see dateerida jutu sisu, tavaliselt jääb selgusetuks, mis ajast ja kust see informatsioon tegelikult pärineb. Võimatu on eristada üksteisest eri sugupõlvede jutustusi, mõned lood on isegi rahvusvahelise taustaga. Teine probleem on seotud allikakriitikaga, mis on ajaloouurimise üks oluline nurgakivi. Ajaloolasele on oluline allika usaldusväärsus, ja selle kindlakstegemise peamiseks meetodiks on eri allikate andmete omavaheline võrdlemine. Rahvatraditsiooni puhul ei ole aga võimalik kasutada sellist allikakriitikat. See on üks põhjus, miks ajaloolased on suhtunud pärimusse ettevaatlikult ja pidanud enamasti paremaks selle kasutamist uurimistöös üldse vältida. See on aga loonud olukorra, et mitmed teemad jäävad uurimisest välja või saab neid käsitleda ainult osaliselt, sest just rahvapärimus aitab heita valgust mitmetele probleemidele, mille kohta kirjalikes allikates informatsioon puudub.

Ajalooteaduse ja rahvaluule tihedamad seosed hakkasid Euroopas elavnema 20. sajandi viimasel veerandil. Üheks põhjuseks oli seejuures nn uue kultuuriajaloo esiletõus (Burke 2006: 201-210). Senise peamiselt kvantitatiivse suunaga majandus- ja sotsiaalajaloo arenguvõimalused olid selleks ajaks ammendunud ja uuesti hakati tähelepanu pöörama subjektile (Tamm 2014: 91-94). Esmalt tärkas huvi argiinimese tegevuse ja selle tähenduse vastu seoses Itaalia mikroajaloolaste töödega (Ginzburg 2000). Keskseks muutus püüd mõista seda, kuidas inimesed mõtlesid (Peltonen 1999: 18-20). Seda võimaldasid välja selgitada mõned traditsioonilised allikaliigid, eelkõige kohtuprotokollid, kuid neil on siiski enamasti teatud kitsam spetsiifika. Teine võimalus oli pöördumine rahvatraditsiooni poole. Seoses tähelepanu osutamisega rahvakultuurile või folkloorsele kultuurile kerkis küsimus kahe kultuurimudeli, folkloorse kultuuri ja haritlaskultuuri omavahelistest seostest (Tamm 2000: 298).

Rahvaluule- ja ajaloo-uurimise suhetes sai 1980. aastatel Peter Burke järgi alguse uus, vastastikuse lähenemise periood, mis järgnes nende paralleelse arengu etapile pärast 1920. aastatel toimunud teadusvaldkondade ja nendega tegelevate institutsioonide iseseisvumist (Burke 2004: 135-136; Jaago 2014a: 88). Rahvaluule seisukohalt on see tähendanud uue uurimissuuna - pärimusliku ajaloo - esiletõusu, kusjuures see areng on olnud niivõrd kiire ja märkimisväärne, et lühikese aja jooksul on jõutud varasemast etapist, mis tegeles rahvalike minevikupiltide väljaselgitamisega ja nende võrdlemisega ajaloopiltidega, juba järgmisse, milles on huvi keskmes minevikupiltide loomis- ja kasutusviisid (Jaago 2014b; Jaago 2014c).

Peter Burke järgi peaks mälule tuginev teadmine huvitama ajaloolasi kahel põhjusel. Esiteks on vaja uurida seda kui ajalooallikat, et hinnata mälestuste usaldusväärsust traditsioonilise allikakriitika abil. Seejuures on varasemate perioodide uurijatel vaja arvesse võtta, et paljudesse kirjalikesse allikatesse 
on talletatud suulisi tunnistusi ja traditsioone. Teiseks tuleks pöörata tähelepanu mäletamise sotsiaalajaloole (Burke 2006: 55-56). Ühiskondliku mälu edasiandmisel on Peter Burke toonud esile viis vahenduskanalit, milleks on suulised traditsioonid, memuaarid ja muud kirjalikud ülestähendused, kujutised, tegevused ja ruum. Nendest esimese, suulise traditsiooni puhul võib Euroopa varase uusaja uurimisel märgata, et aja jooksul on kahanenud lootus tuvastada objektiivseid fakte, kuid kasvanud on huvi narratiivi sümboolsete aspektide vastu (Burke 2006: 56).

Eestis on ajaloolased 1980. aastatest alates hakanud väärtustama mälestusi ajalooallikana (vt lähemalt nt Jaago 2014a: 88-89). Ajalooteaduses on rohkem tähelepanu pööratud teemadele, mille uurimises on pärimusel oma kindel koht. Traditsioonilised allikmaterjalid - mitmesugused revisjonid, kaardimaterjal, kohtuprotokollid, arveraamatud - on tekkinud enamasti mingi riigi- või omavalitsusameti tegevuse tulemusel ja on suunatud konkreetse ülesande täitmisele, mistõttu nende teated on sageli napid ja ühekülgsed. Ajaloolise allikmaterjali ja rahvapärimuse põimimine võimaldab laiendada uuritavate teemade ringi, muutes samal ajal käsitluse mitmekülgsemaks ja luues võimaluse näha ka seda, kuidas inimesed mõtlesid ja mida oluliseks pidasid.

Käesolevas artiklis on vaatluse alla võetud viis asustus- ja agraarajaloo valdkonna teemat, mille puhul on jälgitud, mida võib rahvatraditsioon ühe või teise probleemi uurimisel juurde anda. Tegemist on selliste küsimustega, mis on otseselt seotud rahva eluga ja vastust on otsitud küsimusele, kuivõrd suurel määral on võimalik pärimuse abil traditsioonilistel allikatel põhinevat pilti usaldusväärsel moel täiendada ja selles uusi vaatenurki leida.

\section{Puud ja piiritähised}

Puudele ja teistele silmapaistvatele loodusobjektidele on rahvatraditsioonis vägagi palju tähelepanu pööratud (Viires 1975; Hiiemäe 2007: 271-275). Nende hulgas moodustavad omaette rühma lood, milles on juttu Karl XII poolt istutatud puudest ja sellega seoses öeldud sõnadest. Eestis on kokku teateid rohkem kui 65 sellise puu kohta, nende hulgas on nii tammesid, mände, pärnasid kui ka teisi puuliike. Ajaloosündmuste kulg Karl XII viibimise ajal Eesti alal on hästi teada: tegelikult istutas Karl XII siin puid ilmselt ainult ühel korral, täpsemalt kolm pärnapuud Laiuse kirikuaeda. Siit võib selgesti näha, kuidas need sündmused on hakanud rahvasuus elama oma elu ja lood puude istutamisest on levinud isegi setude puhul, kes Rootsi võimu alla ei kuulunudki. Kuigi võib öelda, et nende juttude puhul on tegemist müüdiga, ilmneb nendes selge rahva suhtumine. Kui täpse sõnastuse "vana hea Rootsi aeg" leiame rahvaluulema- 
terjalidest esimest korda alles 19. sajandi lõpust, ja see on ilmselgelt laenatud kirjandusest, siis arvukates lugudes Karl XII istutatud puudest ilmneb rahva valdavalt positiivne suhtumine Rootsi võimuperioodi (Tarkiainen \& Tarkiainen 2014: 10-12).

Juba mitu aastasada enne Rootsi aja algust, pärast Eesti ala vallutamist sakslaste ja taanlaste poolt 13. sajandil, hakkasid siin kehtima uut tüüpi feodaalsed omandisuhted. Siinsed uued maahärrad hakkasid maid läänistama oma vasallidele, mida hakati tõendama kirjalike dokumentide, läänistamisürikutega. Nendesse märgiti nimeliselt läänistatud külad, veskid ja üksikud talud ning 14. sajandist alates hakati üha sagedamini kirja panema täpsemalt ka piiri kulgu ja piiritähiseid, et vältida riide ja paika panna majanduslikke mõjupiire. Sellega seoses hakkas seni kasutusel olnud laiem piiriruum (vööndi- ehk tsoonipiir) asenduma lineaarse piiriga. Piiri mahamärkimisega seoses toimus keskajal tavaliselt piiri ülevaatamine, mille puhul piirikomisjoni liikmed ratsutasid nii maaomanike kui ka talupoegade juuresolekul piiri läbi. Vanade usaldusväärsete talupoegade ülesandeks oli see piir meelde jätta. Kui hiljem tekkis riid või vaidlus piiri kulu kohta, siis kutsuti needsamad mehed kohtu ette tunnistust andma (Tarkiainen 2011: 17-19). Seega säilis kõnesolev traditsioon läänistamisürikus leiduvale lisaks ka suulisel moel - vanade auväärsete meest mälus olnu ja nende suust kuuldu on piiririidude puhul ka kirja pandud.

Kõige parema pildi valduste piiridest annavad kirjalikud allikad, eelkõige selleks spetsiaalselt alates 17. sajandi keskpaigast joonistatud piirikaardid, aga ka hilisemad mõisakaardid, kus on täpselt näha kogu piir ja piiritähised. Kõige vanemateks piiritähisteks on olnud kraavid, augud, aga peamiselt piirikivid ja -puud, millele oli tavaliselt rist peale tehtud. Puid kasutati piiritähistena kogu 17. sajandi jooksul ja veel hiljemgi, kuigi maamõõtjatele antud instruktsioonides keelati 17. sajandi lõpul piiri mahamärkimisel puude kasutamine, sest neid oli kerge maha raiuda ja nad võisid oma kuju muuta (Tarkiainen 2009: 347; Tarkiainen 2012a: 57).

Rahvatraditsioonis on teated maavalduste, eelkõige mõisate piiride kohta siiski haruldased ja enamasti on need seotud mingi ebatavalise loodusobjektiga. Üksikute puude kohta on rahvatraditsioonis palju lugusid, kuid enamasti on olnud tegemist tähtsate maamärkidega, millel on küla elanike elus olnud oluline koht. Nii näiteks on Väätsa küla männi kohta kaks teadet, mis suure tõenäosusega käivad ühe ja sama männi kohta, kuigi nad on sisu poolest erinevad:

Vahimänd. Väätsa mõisa ja valla piiril kasvab suur mänd, selle otsas valvanud vanasti sõja ajal alati vaht. Mingisugust hädaohtu märgates annud ta sealt kohe märki rahvale ärapõgenemiseks. (E IX 26 (83)< Türi.) 


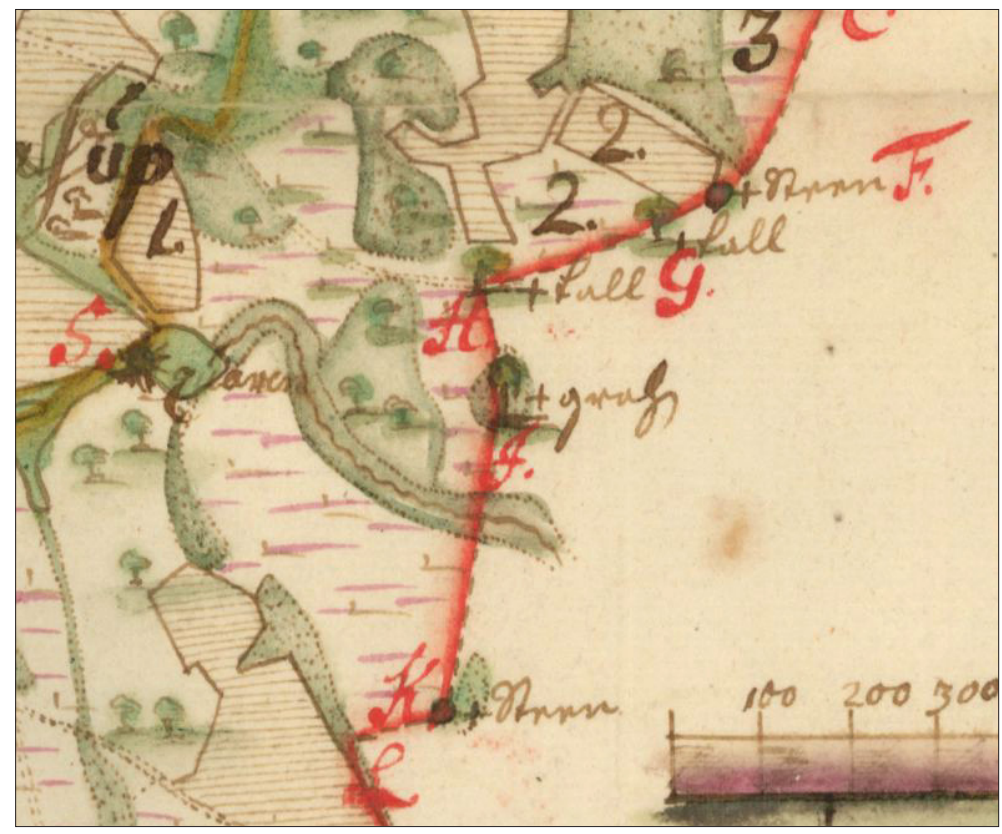

Illustratsioon 1. Ristiga piiripuud ja -kivid Rõuge ja Viitina piirikaardil 1694. aastal (EAA.308.2.179).

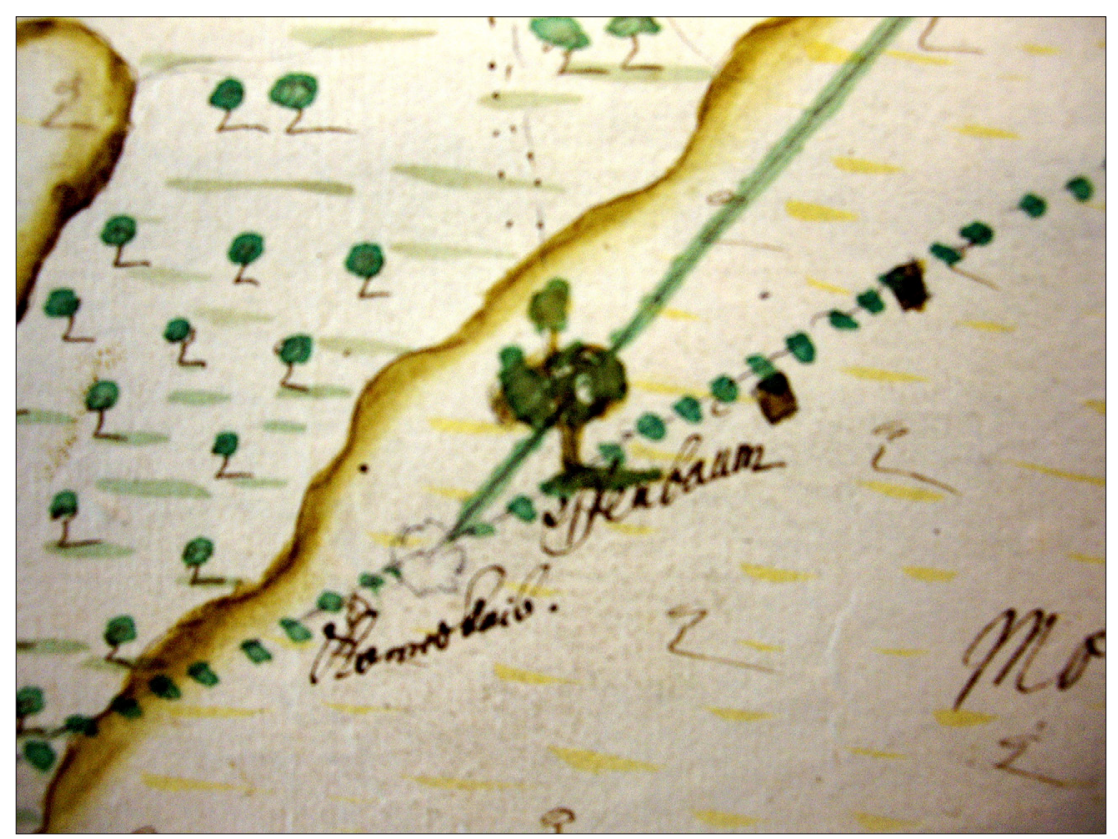

Illustratsioon 2. Piiripuu Lihula ja Seira mõisa piirikaardil 1665. aasta paiku (EAA.858.2.3355). 
Mänd Väitse [Väätsa] küla juures, kuhu mõekadega Rootsi sõja ajal ristid peale tehtud. (EÜS VIII 637 (179) < Türi.)

Selle loo puhul on huvitav, et räägitakse küla piirist. Igal külal oli oma saras, kuid külakaarte on 17. sajandist säilinud ainult üksikuid, enamasti jäävad mõisate kaartidel külade piirid tähistamata. Pärimuses männist Väätsa küla piiril on ilmselt segunenud tegelikkus ja fantaasia. Sellele, et seal on kasvanud tähelepanuväärne mänd, viitab ka teisel pool Lokuta jõge paiknenud voore nimi Männimägi (http://www.rahvakultuur.ee/Vaatsa-Vallavalitsus?v=264\&o=9731). Oli täiesti võimalik, et 17. sajandi alguse sõdade ajal ja ka Põhjasõja ajal võis küla piiril keegi vahis olla. Väätsa oli tihe ridaküla, Männimäelt oli hea ülevaade piki teid lähimate keskuste, nii Paide kui ja Türi suunast saabuvatele vägedele (EAA.3724.4.520). Põhjasõjale viitab küll ka teine lugu, kuid pärimus selle kohta, nagu oleks männile mõõkadega ristid peale lõigatud, ei tundu kuigi usutav, sest mõõk on puukoorde märgi tegemiseks üsnagi ebasobiv vahend. Pigem avaldub selles seos sõjaajaga ning võib-olla ka seostuvad sellega teised müüdid, näiteks sellest, kuidas Aleksander Suur raius mõõgaga lahti Gordioni sõlme või Peeter Suur muutis mõõga abil riikide piire. On siiski huvitav, et kuigi võib olla üsna kindel, et need lood käivad ühe ja sama puu kohta, on nad sisu poolest täiesti erinevad, mis näitab, et kõige märkimisväärsem oli männi olemasolu, mitte aga sündmused, mida on sellega seostatud.

Rohkem tähelepanu on pärimuses pööratud paikadele, kus ristusid mitme mõisa piirid ning mille tähistamine oli erilaadne.

Nii räägib vanarahva suu, et Rannu kooli lähedal "Pärnamäel" asuva kolme iidse pärna kolmik on istutatud vanasti Rannu, Konguta ja Valguta mõisaomanike poolt mõisate piiride kokkuleppimise puhul, kus juures Rannu ja Konguta härrad üksteisele kätt andes piirides kokkuleppinud, kuna Valguta oma ei ole teistele kättandmisega kokkulepet saavutanud. Sellest tulenenudki nende 3 istutatud pärna juures see looduse ime, kus Rannu ja Konguta härrade istutatud pärnapaar on umbes mehe rinna kõrguselt oksakaudu imestusväärselt kokku kasvanud, kuna kolmas pärn seisab pärnade grupis eraldi. (RKM I 7, 451 (1) < Kolga-Jaani A. K. Melso (1964).)

Mitme mõisa piiride ristumiskohad on olnud väga tähtsad piiripunktid, juba 17. sajandist pärit kaartidel on need alati selgelt esile toodud. Selles loos vastab tegelikkusele asjaolu, et Rannu, Konguta ja Valguta mõisa piirid on tõepoolest ühes punktis kokku puutunud. Ka kasutasid maamõõtjad piiri tähistamisel veel 17. sajandil sageli puid piiritähistena, sest need paistsid hästi silma ja nendega ei olnud vaja palju vaeva näha, kuid juba 18. sajandil ja eriti 19. sajandil need 
enam selleks otstarbeks ei kõlvanud. Väide, nagu oleksid mõisaomanikud sellel kohal piiri määramiseks kokku saanud, on tõenäoliselt ainult rahvajutt, mis on tekkinud seoses puude ebatavalise paiknemisega ja sellele on lisatud ka veel episood käesurumisest, mis oli talurahval tavaliseks lepingu kinnitamise märgiks.

Mõisate piir oli 18.-19. sajandil tähistatud nii kupitsate kui ka piirikividega, kusjuures peamiseks ja kõige tähtsamaks tähiseks olid siiski piirikivid. Nad on olnud ka olulisteks maamärkideks, mis on võinud anda nime kogu piirkonnale:

Erra valla metsa on kutsutud nelja mõisa - Püssi, Pada, Erra, Kalsi piirikivi järgi Neljaristi metsaks. (ERA II 217, 235/236 (89) < Rakvere, Lüganuse, Püssi v - Ev. Tarve (1939).)

Kivide kohta on ajaloolises traditsioonis väga palju lugusid. Kirjadega kivisid on seostatud peidetud varanduse, aga ka kuningatega. Pärimuses räägitakse Taani, Saksa, Rootsi ja Inglise kuningatest, kuid enamasti on nende juttude peategelaseks ikkagi kas Karl XII või Peeter I, kes olevat nendel einestanud või lepingut teinud ja selle märgiks kivile märgid peale raiunud.

Raja kivi. Harjumaal Kuusalu külas väljal asub viie ristiga kivi. Räägitakse, et kord raiunud need ristid 5 kuningat, kes kivil einestanud. Teine variant räägib, et see olnud hiiekivi, millele sakslased ristiusu märgid peale raiunud. (ERA II 228, 676/677 (25) Haapsalu l - I. Eller (1939).)

Tavaline on see, et kuigi räägitakse märkidest ja aastaarvudest, ei seostata neid enamasti piiridega:

Hiigla kivi. Võrumaal Vana-Kojula vallas Kivijärve külas järve kaldal rabas on suur kivi, millel on aastaarvud ja muud märgid peal. (ERA II 244, 654 (6) - Põlva, Peri v - Partsi algk. (1939).)

Siin on üsna kindlasti tegemist piirikiviga, sest piiri mahamärkimisel kasutati juba olemasolevaid ebatavalisi loodusobjekte, eriti rabas, kus piiritähiseid oli keeruline püstitada. 1796. ja 1797. aastast pärit Vana-Koikküla, Mooste ja Räpina piirikaardil on Kivijärvest veidi lõuna pool suur ristikivi (EAA.2072.3.58c: 1, 2). Kivijärve läheduses oli veel teisigi ristikive, nii näiteks võib 1831. aastast pärit Vana-Koiola mõisa ja Mooste mõisa vahelise piiri kaardil leida piirikive nii Kivijärve kaldal kui ka järvest veidi eemal metsas, Põlva pastoraadist Räpinasse mineva tee ääres, kuid ühtegi neist ei ole piirikirjelduses nimetatud suureks (EAA.2072.3.58b: 5). On tähelepanuväärne, et seda kivi ei ole piiriga seostatud, see sarnaneb teiste pärimuslike lugudega, milles on juttu kividest, kus olid "kirjad peal”. Mõisate piirid läksid enamasti siiski piki metsi ja soid 
ning olid küladest eemal. Siit võib teha järelduse, et mõisa maavalduste piirid ei ole rahva seas suuremat tähelepanu pälvinud, sest neil ei olnud talurahva igapäevaelus olulist tähtsust.

Seoses talude kruntimisega 19. sajandi teisel poolel sai iga talu oma piiri ja sellele järgnenud päriseksostmise tulemusel eraldati talude maad mõisa maadest. Varasemas üleribasusega külas oli tähtis küla saras, mille moodustasid kõik küla maad, kuid üksikutel taludel (välja arvatud hajatalud) oma eraldiseisev territoorium puudus. Kruntimisega seoses maha märgitud talu piiri kulg oli talule väga oluline ja selle kohta on säilinud vägagi täpseid ja üksikasjalikke teateid. Nendes pööratakse suurt tähelepanu põllupeenarde ja sihtide laiusele ning piiritähistele. Piiritähiseid oli sel ajal kasutusel ainult kaks: piirikivid ja kupitsad.

Kodasoo ja Rummu mõisavallas (Jõelähtme vald) aeti talumaad krunti 1865. aastal. Sel aastal lõpetati kruntiajamine, kuna eeltööd algasid paar aastat varemalt. Piirid märgiti peamiselt ristikividega s.o rajakividega. Piiriks oli sirgjoon kahe naaberkivi vahel. Mingit peenart ei jäetud, kuid põldude vahele kasvas aegamööda kitsas piiripeenar. Heinamaadel ei olnud mingit peenart. Heinaniitmisel pandi ristikivi juurde pikem kepp, mis lõigati lähedal olevatest põõsastest, või teivas, sellele pandi mõni mätas või rohutuust otsa ja peremees või ka teine vanem meesterahvas ajas rajakivi juurde pandud märkide järgi silma järele jäljed rohu sisse. Tagasi tulles rajakivi juurest lõi ta vikatiga jälgede kohalt mõned rohukõrred hõredalt maha, et raja oleks niitmisel paremini näha. Karjamaa rajale ehitati pärastpoole kas puu-või kivitara, mis hoidis kariloomad eemale kas oma talu põldudest ja heinamaadest või naabertalude kruntidest. Piiripeenar kujunes põldude vahele... 50-75 cm laiuseks. Mõnikord oli põllupeenral ka jalgrada. Kohati oli piiril ka põlluvaheline rööbastee. Ristikivi oli lihtne suurem raudkivi, mida ei olnud kerge ühel mehel paigast liigutada. Sellele oli peale raiutud sügav rist, kusjuures need harud, mis ei näidanud raja suunda, olid otsas põiktäkkega suletud. Peale selle olid rajakivile peale raiutud ka ristikivi number. Oli rajal vahest mõni suurem rändrahn, pü̈̈ti raja ajada sellelt kivilt ja rändrahn jäi ka rajakiviks. (ERM KV 124: 270-271.)

Kuna tegemist on suhteliselt hilisel ajal - 19. sajandi teisel poolel - tekkinud nähtusega, on ajaloo uurimise seisukohalt tegemist vägagi usaldusväärse pärimusega. Talurahval oli see igapäevane elukeskkond, ruumiline dimensioon, milles kuni 1940. aastateni suuremaid muudatusi ei toimunud. Seega tundsid jutustajad seda, millest nad rääkisid, väga hästi. Erinevate lugude omavaheline võrdlemine võimaldab välja selgitada eri piirkondades kasutatud piiri märki- 
mise viise ja piiri tähistamise eripära. Sellist informatsiooni arhiiviallikatest ei leia, mistõttu pärimus annab siin olulist lisa maakasutuse uurimisel talude kruntimisele järgnenud ajal.

\section{Külade ja hajatalude rajamine}

Rahvatraditsioonis on üheks vägagi huvitavaks teemaks olnud talude ja külade asutamine. Tavaliselt räägitakse kõige vanemast talust ja küla esimestest asukatest. Küla või talu tekkeloo puhul on sageli viidatud ka selle asutamise ajale. Et Eesti külade võrk oli oma põhijoontes välja kujunenud juba enne 13. sajandit, kajastub rahvapärimuses paljudel juhtudel küla taasasutamine pärast sõda või katku, ja tegelikust asutamisest võib rääkida ainult üksiktalude ja väiksemate külade puhul.

Enamasti ongi ajamääratluseks pärast suurt sõda, teisal mainitakse katkuaegseid talusid. Võib arvata, et sellistes lugudes on viidatud Põhjasõjale ja 1710. aasta katkule, kuid on võimalik, et mõnel juhul on erinevatest perioodidest pärit jutud aja jooksul ühte sulanud ja tegemist võib olla veelgi vanemate aegadega. Nii näiteks pärineb Kursi kihelkonnast järgmine teade:

Peale katku oli Kursis kolm perekonda, üks Tõrvekülas Puutsa talus, teine Hiiu talus, kolmas Kaavel. (EKLA 199, m 51: 22.)

Arhiivimaterjalide põhjal ilmneb, et pärast 1710. aasta katku selles piirkonnas niivõrd ulatuslikku tühjenemist ei olnud. Tekib kahtlus, et tegemist on hoopis mälestustega 17. sajandi algusest Poola ja Rootsi vahelise sõja ajast, millega kaasnes samuti katk ja nälg. Sellega seoses toimus maa ulatuslik laastamine, mis viis paljude külade tühjenemiseni. 1624. aasta revisjoni andmeil oli Tõrvekülas ainult üks asustatud talu, kusjuures veel 1601. aastal oli samas külas olnud üheksa talu ja seitse vabadikukohta (Die Revision Livlands 1601, 1967: 85, Das Dorpater Land 1624/27, 1965: 15). Kokku oli Kursi piirkonnas 1624. aasta revisjoni andmetel asustatud üle 20 talu, kuid nende peremeestest olid pärustalupojad (Erbpauer) vaid kaks, ülejäänud olid mujalt sisse rännanud. Seega oli nimetatud piirkond pärast 1601. aastat tõepoolest inimestest peaaegu tühi ja eespool toodud rahvapärimus võib ulatuda just sellesse aega, kuigi nimede muutumise tõttu ei saa väite paikapidavust täpselt kontrollida.

Talu või küla asutamise juttudes võib täheldada vahet eri perioodidest pärit lugude vahel. Vanima kihistuse puhul on külale või talule aluse panemist seostatud sõja või katku eest kõrvale hoidmisega. Ka räägitakse metsast leitud taludest, mille olevat rajanud põgenikud. Sellistel puhkudel on rõhutatud talu rajaja vaba valikut, mis oli iseloomulik maa laastamisele järgnenud aegadele, 
seevastu hilisemas kihistuses kurdetakse, et talu tuli rajada sinna, kuhu mõis käskis. Ilmselt oli varasemal maade tühjenemisele järgnenud ajal talupojal tõepoolest suuremad võimalused, seevastu 18. sajandi lõpus ja 19. sajandil pidid talupojad toimima vastavalt mõisa ettekirjutustele.

Sageli on külade ja talude asutamise lood olnud seotud teistest rahvustest elanike sisserändega. Enn Tarvel on analüüsinud Kuusalu kihelkonnast pärit teateid sealsete Tapurla ja Viinistu küla asutamisest soomlaste poolt. Mõlemas loos leiab ta omajagu tõtt, kuigi nagu tavaliselt, paistavad tõde ja väljamõeldu olevat segamini, ning küla rajajateks pärimuses mainitud soomlasi pidada ei saa. (Tarvel 1983: 62-66.) Mõnede sedalaadi lugude õigsust on nende ebamäärasuse tõttu raske kontrollida. Kui siiski pärimuses, mille puhul on tegu talu tekkega seoses teisest rahvusest elanike sisserändamisega, võib leida ka ajaloolist tagapõhja, siis lood, mis on seotud küla asutamisega rüütli poolt, võib enamasti lugeda alusetuks. Kuigi 17. sajandi revisjonide järgi elas taludes tõepoolest ratsanikke (Ryttare), on nende lugude taustal nähtavasti hoopis vabaraha maksmine, mis tähendas sageli mõisast kaugemal asunud hajataludele teatud eriseisundit (Liitoja 2000: 122).

Pärimuses on toodud rida põhjusi, miks talud paiknesid küladena - tavaliselt on mainitud vajadust hoida ühte kaitseks röövlite ja varaste, aga ka metsloomade vastu. Siiski leidus hulgaliselt talusid, mis paiknesid kas külasarase serval või metsade keskel. Pärimuse järgi kasvasid sellised üksik- või hajatalud sageli välja puuraiuja või söepõletaja kohast.

Pruuna mõisa suurte rabade taga olid suures kuusemetsas nn laane ääres liivaste küngastega, milledel palju rebase koopaid, täis maa-ala. Sinna saatis Pruuna mõisa tolleaegne parun mehe oma perega elama ja miilama süsi metsa sepikoja jaoks. See pere elas seal nagu vaba metsamehe elu tasuks süte andmise eest mõisale. Elatist tuli hankida perele uudismaad harides põlluks ja sellele külvatud viljast. Mõis lubas pidada ka lehma, lambaid, sigu. Nii võeti iga aasta metsa maha, sellest metsaalusest juuriti põldu. Jõgedest ja kõrvejärvedest püüti kalu. Salamahti kütiti ka hunte ja rebaseid. Juba teise põlvkonna ajal jaotanud mõis metsast ülesharitud maa-ala kahele perele. Nii sai kaks Rebase talu-Eest-Rebase ja TagaRebase. (ERM KV 259: 73.)

Selle pärimuse usaldusväärsuse selgitamiseks on võimalik kasutada adramaarevisjonide andmeid. Selgub, et 1725.-1726. aasta adramaarevisjonis sellenimelist talu veel ei olnud (Järvamaa, 1989: 51, 55-56). 1732. aastaks oli Pruunast juba 17. sajandil eraldatud Põriki mõisa talude seas olemas üks $1 / 4$ adramaa suurune hajatalu, mille peremeheks oli Rebbasse Jahn (EAA.3.1.470: 88-89). 
Võrdlemine 1782. aasta hingeloendiga näitab, et siis oli sama mõisas juba kaks Rebase hajatalu (EAA. 1864.2.IV-6: 355). Kuigi jutustuses ei ole mõisa nimi päris täpne, tundub lugu vägagi tõepärane, ja on alust uskuda, et need hajatalud on saanud 18. sajandil alguse pärimuses esitatud moel. Võib arvata, et rebaste koobastest on tulnud ka talu nimi.

Valdavalt külaasustusega piirkondades olid hajatalud erandlikud ja ilmselt seetõttu on räägitud lugusid sealsete elanike silmapaistvatest omadustest või talu jõukusest. Kuigi on hulgaliselt hajatalusid, mis on olnud 17. sajandi lõpust alates pidevalt asustatud, võisid need ühe pere poolt asustatud talud suuremate katastroofide (sõda, haigused, nälg) ajal kergesti tühjaks jääda. Rahvatraditsioonis on hulgaliselt lugusid neist järelejäänud taluasemetest, mida tähistavad ainult kivihunnikud. Hajatalude kadumise põhjuseks oli ka maade mõisastamine ja nende maadele metsa istutamine. Niisuguseid teateid leidub 19. sajandi esimesest poolest üsna palju, ja enamasti kinnitavad sellise pärimuse õigsust ka arhiiviandmed.

\section{Külapõllud ja talude kruntimõõtmine}

Eesti küladele olid kuni 19. sajandi teisel poolel toimunud talude kruntimiseni tüüpilised ribapõllud, mille puhul paiknesid ühele talule kuulunud põlluribad läbisegi teiste talude omadega, mis tingis väljasunni. Selline ribapõldude süsteem on hästi nähtav juba 17. sajandi 80. aastatest pärit kaartidel, kuid järgnevatel sajanditel on mitmel pool põldude jaotust muudetud, et vähendada ühele talule kuulunud ribade arvu. Väga rikkaliku allikmaterjali moodustavad 19. sajandi alguses toimunud maamõõtmiste tulemusel valminud kaardid koos kaardikirjeldustega, kuhu on lisaks põllu- ja heinamaa pindalale kirja pandud ka maatükkide arv. Külade vahel oli selles osas suuri erinevusi: tükeldatus sõltus talude arvust, põldude paiknemisest ja muidugi ka maamõõtjate otsustest. Laiuse piirkonna suurtes külades ulatusid pikad ja kitsad nöörimaad põllu ühest servast teise, mistõttu ühele talule kuulunud ribade arv oli suhteliselt väike. Teisal koosnes ühe talu põllumaa koguni 20 ribast, millele lisandusid veel võsamaatükid ja heinamaalapid, mistõttu ühe talu maatükkide arv võis ulatuda sajani (Tarkiainen 2006: 229-255).

Kuigi kaarte ja kaardikirjeldusi leidub põllujaotuste uurimiseks palju, ei leia me allikmaterjali hulgast teateid selle kohta, kuidas nendel ribapõldudel tegelikkuses tööd tehti. Ainult rahvapärimuse abil on võimalik välja selgitada, kuidas töö sellistel põldudel välja nägi ja kuidas külaelanikud sellesse suhtusid. Seejuures tuleb arvestada, et rahvapärimus kirjutati üles hiljem, 19. sa- 


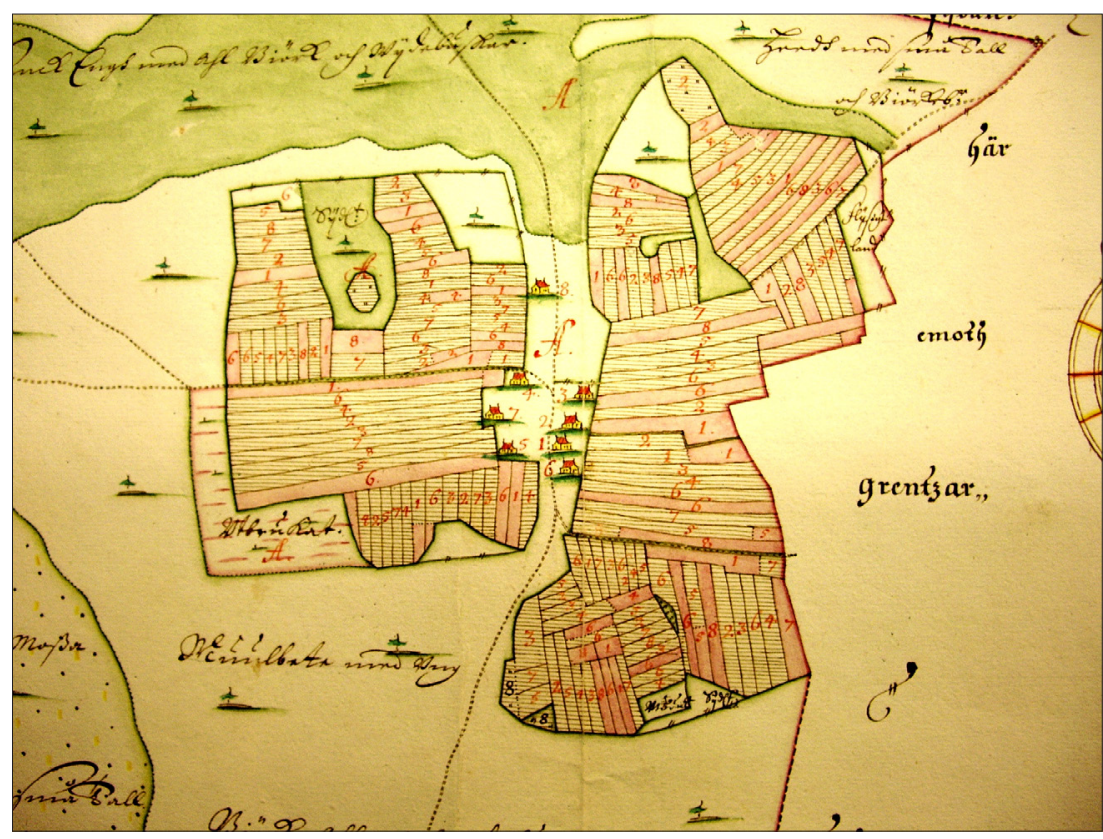

Illustratsioon 3. Harju-Jaani kihelkonna Paasiku küla ribapõllud 1688. aastal (EAA.1.2.C-III-34).

jandi teisel poolel või 20. sajandi alguses, mil külade maad olid juba krunti mõõdetud. Seega on jutustajatel olnud võimalik omavahel võrrelda olukorda ribapõldudega külas versus krunditud taludega külas, mis annab pärimusele juba teatud alatooni.

Paljudes mälestustes kurdetakse üleribasuse ja väljasunniga seotud raskuste üle. Järgnev näide pärineb Viru-Nigula Iila külast, kus põllumaa oli jaotatud kolmeks väljaks: Kirikupoolne, Mõisapoolne ja Mäeväli, mis jagunesid omakorda vastavalt 19, 15 ja 9 põlluribaks. Küla heinamaad jagunesid vastavalt 19,12 ja 9 osaks.

Nende väikeste tükkide peal oli töötegemine väga raske. Töö tuli teha ühel ajal ja ühes kohas. Kui üks pere läks heinamaale või lõikama, pidid ka naabrid kohal olema. Muidu jäid nad oma saagist ilma, sellepärast et põllud ja heinamaad olid väga kitsad. Kes kärmem oli, see korjas ka teise osa, nii et teisele väga vähe järele jäi. Et põllutükid ja heinamaad väga väikesed olid, siis ei saanud ühe koha peal väga kaua tööd teha. Ühe heinamaa tüki peal sai paari inimesega kahed kaared niita, siis oli ta maas. 
Leivamärss ja lähker selga ja jälle järgmise tüki peale. Nii oli hommikust ôhtuni üks kolimine, see oli siis kündmas, lõikamas või heinatööl. Rohkesti aega läks käies ja sättides ühest kohast teise, kui tulusat tööd tehes. [---] Ader oli puust ja põllud kivised, seetõttu läksid sahapuud päeva jooksul mõnikümmend korda katki, nii pidi neid tagavaraks olema, et kohe uued sahapuud sisse panna ja aega kokku hoida. (ERM KV 91: 38-34.)

Sellised pikad ja kitsad põlluribad võimaldasid vaid ühtpidi kündi. Lisaks põlispõldudele oli kõigil küla taludel õigus kasutada küla ühismaid ja seal aletamise teel põllumaad juurde teha. Selliseid metsa- ehk võsapõlde kasutas iga talu eraldi ja nendel ei kehtinud üleribasusega kaasnenud piirangud.

Nii Liivi- kui ka Eestimaal 19. sajandi teisel poolel toimunud talude kruntimine tähendas suurt muutust talurahva elus, ning selle kohta leidub ka palju allikmaterjali, enamasti kruntimisplaanide ja nii mõisa- kui ka talukaartide näol. Kruntimise käigus püüti igale talule välja mõõta võimalikult terviklik territoorium. Talu hooned pidid asuma põldude juures, vaid heinamaad võisid jääda lahustükkidena kaugemale. Tihedates külades ei olnud siiski sageli võimalik sel moel krunte välja mõõta, mistõttu tuli osa talusid külast välja viia. Sel põhjusel tekkisid endise külapõllu teise serva nn väljatagused külad, mida loeti kas vana küla alla või täiesti iseseisvaks külaks.

Rahvapärimuse järgi hädaldasid kõige rohkem just need, kel tuli külast välja kolida, kuigi elumaja jaoks anti mõisa poolt materjal ja valla poolt tööjõud ning rentki oli neil esialgu odavam. Tavaliselt olid talupojad kruntimise vastu või tahtsid saada just neid maatükke, mida olid varem harinud. Kruntimisel ilmnes sageli talupoegade alalhoidlikkus, vastuseis muutustele ja kaasnenud lisatöödele, milleks oli sihtide sisseraiumine nii karjamaadel kui ka metsas ja krundi mahamärkimiseks piirikivide paigutamine. Kruntimisega kaasnes palju riide ja arusaamatusi, rahvas on rääkinud altkäemaksuandmistest ja sellest, et mõnes paigas muutsid maamõõtjad meelehea eest talude piire.

Lõppkokkuvõttes on aga kruntimise tulemusel kujunenud maadejaotuse süsteemi peetud varasemast paremaks. Pärast kruntimist võeti kasutusele mitmeväljasüsteem, millega seoses küll rukki osatähtsus langes, kuid saak nii palju ei langenud, sest põllud olid taludele lähemal, said rohkem väetist ja olid paremini haritud. Kruntimisele eelnenud ajale antud hinnangutes on laiali pillatud põllu- ja heinamaa tükke peetud rahva vaese ja kehva elu põhjusena raske mõisateo ja viletsate põllutööriistade kõrval (ERM KV 91: 46). 


\section{Talude pärimine}

Tõelist varanduse jagamist ei saanud meie esivanematel olla, sest raha oli üldse väga vähe liikvel ja varanduseks võis lugeda ainult loomi ja vilja, aga need olid talupidamiseks tarvilikud, nii et kes mõisahärrale kuuluva talu päris, see pidi ka loomad ja vilja ühes saama ja ... kui mõisahärra kelleltki lohaka teopäevade tegemise pärast talu ära võttis ja teisele andis, siis anti see kõige loomade ja muu varandusega uuele pidajale üle. Nii on tehtud ka minu vanaisaga Tarvastu valla Tossu talus umbes aastal 1830, kus mõisa kilter seda kohta omale tahtis. (ERA II 186, 95/6 (126) < Äksi, Sootaga k - Juhan Johanson (1937).)

Olukord muutus täiesti seoses 19. sajandi teisel poolel alanud talude väljaostuga, mis kulges Liivimaal veidi kiiremas tempos kui Eestimaal (Laur jt 2014). Kui varem oli talupoegadele kuulunud ainult vallasvara, siis nüüd lisandus sellele kinnisvara talu näol, mistõttu pärimissuhted said hoopis uue tähenduse. Traditsiooniliselt pidi talurahvaühiskonnas pere tagama laste kasvatamise ja vanade ülalpidamise ning tegutsema nendel eesmärkidel ühtsena. Teatud mõttes ei kuulunud maa mitte ühele indiviidile, vaid teatud rühmale, kes olid omaniku sugulased, suurim tähtsus oli lastel. Talu omanik võis teha testamendi ja sellega täpselt oma äranägemise järgi kindlaks määrata nii naise kui ka laste osa. Kui testamenti ei olnud, siis toimus 19. sajandi teisel poolel pärimine Liivimaal vastavalt 1849. aasta ja Eestimaal 1856. aasta talurahvaseadusele.

Talude pärimise kohta on olemas rikkalik allikmaterjal, mida säilitatakse enamasti vallakohtute fondides (Traat 1980). Kuna ka rahvatraditsioonis on pärimise kohta säilinud väga palju andmeid, siis väärib tähelepanu, kuidas ajalooallikad ja pärimus omavahel kokku sobivad, kas nende vahel võib näha märgatavaid erinevusi või on see pilt, mis avaneb, üsnagi samalaadne.

Kohtumaterjalid näitavad, et testamentide tegemine muutus 1880. ja 1890. aastatel üha tavalisemaks ja selle (kas siis suulise või ka kirjaliku testamendi) sisu oli hoolika kaalumise tulemus. Suuline testament tehti kodus tunnistajate juuresolekul ja kirjalik vallamajas, see kanti seal valla lepingute raamatusse. Testamendi olemasolu korral toimus vara jagamine nii, nagu selles oli otsustatud. Rahvatraditsioonis on testamendi austamise ja selles kirjapandu järgimist seletatud järgnevalt:

Vanal ajal peeti väga kindlaks sureja tahtmist või soovi päranduse jätmisel. Kirjalikke testamente ei tea kas oligi, rahvas ei mõistnud kirja lugeda ega usaldanud kirjamõistjaid, parem juba lubasid suusõnaliselt tunnistajate kuuldes ehk ilma tunnistajateta, mida kellegile anda tahtsid. Surnu soove pü̈̈ti juba sellepärast täita, et surnu ei tuleks kodukäima ja ülekohtu tegijat karistama. On tänapäevani inimesi, kes surnu soove 
pühaks peavad ja neid täidavad. (ERA I 129, 513 (9) < Märjamaa khk ja v - E. Poom (1936).)

Kuna talu oli toimiv majandusüksus ja pere elatusallikas, siis seda üleminekul ühelt põlvkonnalt teisele ei jagatud. Kinnisvara pärimisel oli mees eelisseisundis, sest tema osa oli naisele langevast osast kaks korda suurem. See oli mõeldud kergendama talu üleandmist meesliinis, et talust väljamakstav summa ei tõuseks liiga kõrgeks (Tarkiainen 2010: 255-280). Talu kirjutati peapärija nimele alles pärast seda, kui peapärija oli kaaspärijatele nende osa välja maksnud.

Enamasti sai uueks peremeheks kõige vanem poeg, kellel oli eesõigus ja seda mitte ainult tavaõiguse, vaid ka seaduse silmis. Rahvatraditsiooni kohaselt hoiti vanemat poega üldiselt kõige rohkem, sest tema pidi ka vanemate eest nende vanaduspõlves hoolt kandma. Pärimuses on rõhutatud, et kuigi esimesel pojal oli suurem õigus isa järel peremeheks jäämiseks, võis isa selle õiguse anda ka hoopis teistele lastele. Seletatud ongi eelkõige juhtumeid, mis olid veidi erandlikud, see nõudis põhjendust, kui kõige vanem poeg talust isa soovil ilma jäeti.

Esimesele pojale sai (varandus). Kui see oli vasta tahtmist, siss sellele, kes mööda tahtmist oli. Minu isal oli seitse venda. Talu ess saa kõege vanemale. See oli söögi lavva juures isale purskand kapsa suppi vastu silmi. Isa ess anna temale talu. Andis tõise naisest sündinu esimesele pojale. Minu isa ja teised velled jäid sinna talu teenima. Kindlat palka ess ole. Röövast anti, jalanõud. Kui isal olli varandust, siss andse tõ'stele kah. Sundust ess teha, et pidi maksma. Perämine naine - lubati eluaja korter selles talus, moon kah. Enamiste oli ika vaenuelu neil. (ERA II 301, 49 (57) < Helme, Patküla v, Pikasilla - Liis Pedajas (1941).)

Kuigi peapärija oligi tavaliselt mees, oli pärimissüsteem siiski paindlik. Kui meespärijaid ei olnud või nad ei sobinud taluomanikuks, siis jäeti koht naisele. Siin ilmneb eelkõige talurahva ratsionaalsus ja arvestamine majanduslike teguritega. Naise ja mehe võimalused olid siiski erinevad, seda tingisid nii majanduslikud kui ka juriidilised tegurid. Kui naine päris talu, läks vastutus selle eest tema mehele. Mehe surma korral jäi alaealiste lastega naine enamasti talu pidama kuni poja täisealiseks saamiseni või tütre abiellumiseni. Siis toimis lesk omandi säilitaja ja edasiandjana (Tarkiainen 2012b: 115-144).

Pärimuses on rõhutatud just seda, et pojad said tavaliselt suurema pärandiosa kui tütred, ka testamendiga lubati tütardele enamasti ainult lehm ja lammas. Sageli ei saanud nad pärandi jagamisel enam üldse midagi, sest nende osa loeti kaasavara näol juba varem saaduks. Ajaloolise traditsiooni põhjal otsustades oligi peamiseks rahulolematuse põhjuseks tütardele langenud osa vähesus: 
Tütred ei sand majast kedagi muud kui kõvast tüed teha ja kui mehele läksid, siis anti riidekraami kaasavarast. Rikkamad pered annid lehma ja lamba, vahel ka põrsa. Isa varandus jagati puegade vahel. (ERA II 193, 312 (8) < Jõhvi khk ja v, Tarakuse k - Armilda Hallik (1938).)

Pärimist pidas rahvas siiski suuresti ka kokkuleppimise asjaks. Kes sai talu, pidi hoolitsema ema eest. Kui peremehest isa suri ja lapsed olid väikesed, jäi koht ema nimele. Emale oli talu pidamisel abiks kas ema enda või mehe vanem vend. Naised on talupidajatena olnud siiski ainult ajutiseks vahelüliks: kui poeg oli saanud täisealiseks, siis sai peremeheks tema. Lese seisund sõltus otseselt laste olemasolust, kui lapsi ei olnud, siis läks talu lähisugulaste kätte, kes suutsid paremini talu pidamisega hakkama saada:

Kui naine leseks jäi lasteta, siis pärandust ei saanud ja samuti lasteta koduväimees leseks jäämise korral pidi lahkuma talust päranduseta neid loeti “teenijaks”. (ERA II 135, 231 (2) < Torma, Lohusuu v, Kalma k, Mutuska t - M. Särg (1937).)

Kuna pärimisel oli rahva elus väga oluline koht, kajastub see teema vägagi olulisel määral ka pärimuses. Nii arhiiviallikate kui ka rahvatraditsiooni sisu langeb üldjoontes väga hästi kokku. Pärimus lisab siia aga ajalooallikates nähtamatu poole, mis ilmneb pärijate suhtumises oma pärandiosa suurusesse. Eriti selgelt ilmneb, et naised olid pärandi jagamisel meestest palju viletsamas seisundis, mistõttu nad ei olnud sageli nendele langenud osaga rahul.

\section{Kerjused}

Kuni 18. sajandi lõpuni oli Baltimaade agraarkorralduses kesksel kohal mõisniku eestkoste, mistõttu vaeste, haigete ja vanurite eest hoolitsemise kohustus lasus mõisnikul (Laur 2000: 163-165). Liivimaal anti kindralkuberneri patendiga 1818. aastast vaestehoolekanne vallakogukonna hooleks (Traat 1980). Vaestehoolekandega seotud teemasid on enamasti vaadeldud mitmeid kohtuinstitutsioone puudutavates uurimustes, kusjuures olulise tähtsusega on vallakohtute kõrval ka sillakohtute materjalid (Seppel 2002). Võitlus kerjamise ja hulkurluse vastu olid eriti tähtsal kohal nii kindralkuberneri kui ka politsei patentides (Taela 2015). Maal ringihulkuv kerjus tuli kohe kinni pidada ja saata oma kodukohta. On tähelepanuväärne, et kuigi pärimuses on kerjuste kohta väga palju lugusid, ei käsitleta neis kerjuste väljasaatmist. Seega jääb see õiguslik ja politseiline aspekt rahvatraditsioonis tähelepanu alt täiesti välja.

Kõiki vaeseid on 19. sajandi sillakohtu materjalides kutsutud kerjusteks (Bettler) ja nende kohta on olemas üsnagi ulatuslik allikmaterjal, milles tehak- 
se küll vahet vaeste ja nn tõeliste kerjuste vahel, kusjuures viimatimainitute hulka arvati need, kes elasid almustest. Kreiside kaupa on kogutud statistilisi andmeid, millest ilmneb iga abivajaja nimi, vanus, vaesusse langemise põhjus, elukoht ja see, millist abi ta kogukonnalt saab. Vaesteabi koosnes tavaliselt moona jagamisest, kusjuures magasiaidast said vaesed enamasti rukist, nisu ja otri. Vaesteabi alla kuulusid endiselt eelkõige vanad, aga ka haiguse või puude tõttu töövõimetud. Kõige raskemas olukorras olidki nn tõelised kerjused, kes käisid külakorda või kogusid almuseid kiriku uksel, aga ka talust talusse kerjates (Tarkiainen 2016).

Kerjamise puhul tekkis kahe inimese vahel mitteisiklik kontakt. Almuse andmine ja vastuvõtmine ei tekitanud nende vahele sidemeid, sellega ei kaasnenud kohustust saadut tulevikus kuidagi korvata. Annetada võis kõike, kuid annetajale ei võinud see olla suur kaotus (Archard 1979: 39-40). Kerjustesse suhtumine oli salliv: neile anti alati nii öömaja, süüa kui ka almust. Euroopa kultuuriruumis oli selle aluseks kristliku halastuse põhimõte ja see oli omamoodi religioosne akt. Kui oled vaese vastu hea, siis on sul õnne, kui sulged vaese ees ukse, tabab sind ebaõnn (Häkkinen 1992: 157). Selline kristlikust vaimust kantud suhtumine ilmneb ka järgneva loo puhul:

Vanasti oli üks valla sant linna tänavale ära surnud. Samal hetkel hakkasid kirikukellad lööma, sest sant olnud püha mees. Rahvas mattis vaese auga maha. (ERA II, 243, 609 (23) < Hargla, Vana-Roosa vald Vastse-Roosa algk (1939).)

See elanikerühm oli küla hindava pilgu ja kontrolli all (Häkkinen 1992: 156; Häkkinen 2005: 225-262). Neisse suhtuti üldiselt ettevaatlikult ja oli tavaline, et nõdrameelseid sante ka narriti. Enamasti tehtigi vahet oma valla inimeste ja kaugemalt tulnud kerjuste vahel. Kerjuseid puudutav ajalooline traditsioon on väga konkreetne, räägitakse konkreetsetest inimestest, mainides neid nimeliselt, kasutades enamasti nende kohta käivaid hüüdnimesid:

Hulkuritest. Kerjamas käisid Sontka (Leena Mihkelson), kelle isa olnud aasta läbi laisk. Ainult enne jõule teinud tööd. Sontka olnud must ja ropp. Atsaka Leenu (Leena Talts), kes õnnetusest rumalaks jäänud. Olid veel Aseri Jaan (Jaan Toiger), Vasta Prits, Kopli Kaarel, Ulja Uude. Kopli Kaarel oli óppimisega hulluks läinud. Oli puhas ja korralik, ka tark noormees. (ERA II 218, 330/3 (15) < Viru-Nigula, Kunda-Malla v, Kurek. - H. Piispa (1939).)

Erilaadseid lugusid võrreldes ilmneb, et tähelepanu pöörati enamasti siiski ühtedele ja samadele asjadele. Esimesena võib välja tuua kerjuse päritolu ja mainet. Enamasti toodi välja põhjus, miks üks või teine inimene on sattunud 
sellisesse olukorda, et peab elama almustest. Kerjamise põhjus ei peitunud siiski mitte alati üksnes psüühilises või füüsilises haiguses, vaid selleks võis olla ka lihtsalt laiskus, viitsimatus tööd teha. Kõige põhjalikumad on seletused juhtudel, kui on tegemist nõrgamõistuslikkusega, mille kohta kasutati enamasti väljendit "rumalaks jäänud". Ühe põhjusena on esile loodud liigset õppimist, nii nagu see ilmneb ka eelpooltoodud näitest. Tavalisemaks seletuseks on siiski kas mingi õnnetusjuhtum või vägivald, aga ka vägistamiskatse.

Kussma Anne. Veriora vallas Soohara külas elas sant Kussma Anne. Noorena olevat ta väga ilus olnud ning mõisa noorhärra tahtnud temast armukest teha. Anne hakkas vastu ning noorhärra ähvardas teda tappa. Anne jäi sellest ehmatusest rumalaks. (ERA II, 290, 516/517 (28) < Räpina, Veriora v, Süvahavva k - D. Lepson (1940).)

Teisena võib näha, et tavaliselt pöörati tähelepanu kerjuse välimusele, eelkõige puhtusele, aga ka tema iseloomule ja erilistele kommetele. Kerjusel oli tavaliselt kaasas kott ja kepp, ning just viimatimainitu võis olla tema eriliseks iseärasuseks, samal ajal kui mõne teise puhul oli selleks lauldes ringikäimine. Enamasti oli tegemist ainult mõne kindla käitumisviisi või kombega, mis oli iseloomulik ainult ühele kerjusele ja seda räägiti ilmselt seletamaks tema hüüdnime, kas oli selleks keppide kogumine või piitsa kaasaskandmine. Kui enamasti olid santidega seotud jutud mõeldud nende eripära rõhutamiseks, siis mõningatel juhtudel mõjuvad need selge hoiatusena ja manitsusena ettevaatusele, mis oli kindlasti omal kohal ka külakorras käijate puhul. Eriti halvaks peeti seda, kui sant varastas.

Kiigra Leena. Partsi ümbruses Palomõisas elas Kiigra Leena, kes oli sant. Ta oli oma olemuselt väga kerglane ja naljakas. Seal talus, kus ta süüa sai kirus eelmist pere taga ning järgmises kohas jällegi eelmist. (ERA II 290, 513/515 (27) < Räpina, Leevi v, Palomõisa as. - D. Lepson (1940).)

Kolmandaks pöörati tähelepanu kerjuse oskustele. Kaugemalt tulnud kerjused pidid nägema rohkem vaeva, nad mängisid sageli mingit pilli ja lugesid ning laulsid enamasti vaimulikel teemadel. Eriti hinnatud oli jutustamisoskus, aga ka võime tulevikku täpselt ette kuulutada.

Kurismiku sant. Oli pärit Kurismiku külast. Oli vana soldat, kerjas. Oli täpne ettekuulutaja, aga ka hea jutustaja. (ERA II 218, 69/71 (8) ViruNigula, Kunda-Malla v, Letipea k - E. Meriloo (1939).)

Kaarepere vallas elanud valla sant. Mart Purk oli kuulus oma suure jõu poolest. Ta teinud palju vägitegusid ja teadnud palju jutte. Kord tõstnud 
ta kõrtsis hammastega viina vaadi, mille sees olnud pang õlut. (ERA II, 247, 141 (23), Räpina, Kahkva, Suure-Veerusu - A. Hiietamm (1939.).

Rahvajuttudes pajatatakse ka mõnest sellisest kerjusest, kes oli tegelikult rikas, kuid nii ihne, et ei raatsinud isegi süüa. Sellised lood lõpevad moraaliga: "pärastpoole võeti see mees kinni ja sai vangistust". Kui ametivõimudele tekitasid muret teedelt surnuna leitud kerjused, siis rahvasuust üleskirjutatud juttudes oli metsast leitud kerjuse juures enamasti ka rahaga täidetud kotike. Külainimeste silmis olid sandid siiski võõrad, kellest räägiti ja kelle kombeid pandi tähele.

Kerjuste puhul ilmneb, et see pilt, mis avaneb ajalooallikatest ja rahvatraditsioonist on suuresti erinevad, sest nad keskenduvad täiesti eri aspektidele. Võimude püüd kerjamist välja juurida ja kerjuseid nende kodukohta tagasi saata rahvapärimuses ei kajastu. Kui arhiivimaterjalides on kirja pandud iga vaese kohta võimalikult täielikud andmed, siis pärimuses keskendutakse enamasti ainult ühele aspektile, kas selleks oli siis välimus, iseloom või erilised oskused, mida ühe või teise puhul kõige olulisemaks peeti. Rahvapärimuse puhul ongi eripäraks just see, kuidas külarahvas nendesse suhtus ja mida rääkis, ning see erineb suuresti arhiiviallikate täpsusest, kuid annab nähtusele täiesti teistlaadse dimensiooni.

\section{Kokkuvõte}

Rahvapärimuse kasutamise võimalused ajaloo uurimisel sõltuvad otseselt püstitatud probleemist.

Kaugemasse minevikku ulatuvates mälestustes on tegelikkus ja väljamõeldis sageli segunenud, mistõttu ajaloolaste silmis on selliste lugude usaldusväärsus madal. Sellelaadne pärimus näitab siiski, mida on väärtustatud, millised sündmused on tundunud tähelepanuväärsed ja olulised.

Pärimus külade ja talude asutamise ning nende esimeste asukate kohta on enamasti seotud sõja- ja katkuajaga, inimeste sisserändega või mingi muu ebatavalise sündmusega. Rahvamälestustes hulgaliselt leiduvates olustikulistes kirjeldustes on tavaliselt räägitud sellest, mida hästi tunti. Rahvatraditsioonis avalduv aitab oluliselt elavdada arusaamu minevikust ning võimaldab välja selgitada talurahva suhtumist ja hinnangut ühele või teisele sündmusele või nähtusele. Ajaloopilt muutub pärimuse arvessevõtmise tulemusel palju diferentseeritumaks ja värvikamaks. Eriti usaldusväärne on selline hiline ajalooline traditsioon, mis on pärit keskkonnast, kus ruumilised suhted on jäänud pikema aja jooksul muutumatuteks. 
Artiklis vaatluse alla võetud pärimus on tihedalt seotud külaühiskonnaga ja selles ilmnevad eelkõige talupoegade argieluga seotud arusaamad, mida arhiiviallikad valgustavad enamasti hoopis teisest vaatenurgast. Kõige suurema erinevusena tõusebki esile, et otse loomulikult jäävad arhiivimaterjalides kajastamata mitmete nähtuste põhjused, mis ei peitu tegelikult üldsegi materiaalses maailmas, vaid talupoegade mõttemaailmas. Võib väita, et rahvas on oma juttudes andnud enda poolt seletatud nähtustele hinge. Just seetõttu võimaldab rahvapärimuse kasutamine asustus- ja agraarajaloo uurimisse tuua olulise lisa, mis täiendab ratsionaalset pilti toimunud sündmuste ja protsesside kohta ning võimaldab avada toimunu sügavamaid põhjuseid.

\section{Kommentaarid}

1 Artikkel on valminud sihtfinantseeritava teema nr SF0180006s11 raames.

\section{Arhiiviallikad}

\section{Eesti Kirjandusmuuseum}

\section{Eesti Rahvaluule Arhiiv}

E - Matthias Johann Eiseni käsikirjaline rahvaluulekogu aastaist 1880-1934.

ERA I, II - Eesti Rahvaluule Arhiivi rahvaluulekogu.

EÜS - Eesti Üliõpilaste Seltsi rahvaluulekogu.

RKM I - Eesti RA Fr. R. Kreutzwaldi nim Riikliku Kirjandusmuuseumi rahvaluule osakonna rahvaluulekogu.

\section{Eesti Kultuurilooline Arhiiv}

EKLA 199 - Akadeemilise Ajaloo Seltsi (1920-1940) stipendiaatide välitöö-aruanded (Ajaloolist traditsiooni Eesti kihelkondadest).

\section{Eesti Rahvusarhiivi ajalooarhiiv (EAA)}

EAA.3.1.470. Revision im Jahre 1732. Spezifikationen und Wackenbücher des Jerwischen Distrikts.

EAA.1864.2.IV-6. 1782. aasta hingeloend. Põriki mõis.

EAA.2072.3.58b. Vana-Koiola ja Mooste mõisa piir 1831.

EAA.2072.3.58c. Vana-Koila, Räpina ja Mooste mõisa piir 1796, 1797.

EAA.3724.4.520. Väätsa mõisa kaart 1853-1855.

Eesti Rahva Muuseum (ERM)

ERM KV - Korrespondentide vastuste arhiiv. 


\section{Allikapublikatsioonid}

Das Dorpater Land 1624 / 27 1965. Hefte zur Landeskunde Estlands. Heft 1. Hrsg. Oleg Roslavlev. München: Akademie Druck.

Die Revision Livlands 1601. Estnisches Siedlungsgebiet 1967. Hefte zur Landeskunde Estlands. Heft 3. Hrsg. Oleg Roslavlev. München: Akademie Druck.

Eestimaa 1725.-1726. a. adramaarevisjon. Järvamaa. 1989. Allikapublikatsioon. Tallinn: [Eesti NSV Riiklik Ajaloo Keskarhiiv].

\section{Interneti-allikad}

Rahvakultuuri Keskus: Väätsa vallavalitsus, http://www.rahvakultuur.ee/VaatsaVallavalitsus? $\mathrm{v}=264 \& 0=9731$ (13. oktoober 2016).

\section{Kirjandus}

Archard, Peter 1979. Vagrancy, alcoholism and social control. London: Macmillan.

Burke, Peter 2006. Kultuuride kohtumine. Esseid uuest kultuuriajaloost. Tallinn: Varrak.

Burke, Peter 2004. History and Folklore: A Historiographical Survey. Folklore 115 (2), lk 133-139 (doi: 10.1080/0015587042000231237).

Ginzburg, Carlo 2000. Juust ja vaglad. Ühe 16. sajandi möldri maailm. Tallinn: Varrak. Hiiemäe, Mall 2007. Sõnajalg jaaniööl. Tartu: Ilmamaa.

Häkkinen, Antti 1992. On attitudes and living strategies in the finnisch countryside in the years of famine 1867-68. Häkkinen, Antti (toim). Just a Sack of Potatoes? Crisis Experiences in European Societies, Past and Present. Studia Historica 44. Helsinki: Suomen Historiallinen Seura, lk 149-166.

Häkkinen, Antti 2005. Kiertäminen, kulkeminen ja muukalaisuuden kohtaaminen 1800-luvun lopun ja 1900-luvun alun maalaisyhteisössä. Häkkinen, Antti \& Pulma, Panu \& Tervonen, Miika (toim). Vieraat kulkijat - tutut talot. Näkökulma etnisyyden ja köyhyyden historiaan Suomessa. Historiallinen arkisto 120. Helsinki: Suomalaisen Kirjallisuuden Seura, lk 225-262.

Jaago, Tiiu 2014a. Minevikufaktid ja minevikuesitused. Mäetagused 56, lk 83-102 (doi: 10.7592/MT2014.56.jaago).

Jaago, Tiiu 2014b. Pärimuslik ajalugu - arengusuunad ja paralleelid. Mäetagused 56, lk 7-20 (doi: 10.7592/MT2014.56.sissejuhatus).

Jaago, Tiiu 2014c. Rahvaluule, ajalugu ja "pärimuslik ajalugu”. Keel ja Kirjandus 6, lk 418-435 (http://kjk.eki.ee/ee/issues/2014/6/506 - 12. oktoober 2016).

Laur, Mati 2000. Eesti ala valitsemine 18. sajandil (1710-1783). Tartu: Eesti Ajalooarhiiv. 
Laur, Mati \& Lust, Kersti \& Pirsko, Priit \& Tarkiainen, Ülle 2014. Talude päriseksostmine. Pärnumaa andmestiku põhjal. Tartu: Eesti Ajalooarhiiv.

Liitoja, Ülle 2000. Külad ja hajatalud eesti rahvatraditsioonis. Šor, Tatjana (koost). Kultuurilised ekskursid. Eesti Ajalooarhiivi toimetised 6 (13). Tartu: Eesti Ajalooarhiiv, lk 119-134.

Peltonen, Matti 1999. Mikrohistoriasta. Helsinki: Gaudemus.

Seppel, Marten 2002. Sillakohtu ellukutsumisest Liivimaal. Küng, Enn (koost). Läänemere provintside arenguperspektiivid Rootsi suurriigis 16/17. sajandil. Eesti Ajalooarhiivi toimetised 8 (15). Tartu: Eesti Ajalooarhiiv, lk 189-204.

Taela, Aliide-Marie 2015. Liivimaa politseikorraldused vaeste ja kerjuste küsimuses enne pärisorjuse kaotamist. Bakalaureusetöö. Tartu: Ajaloo- ja arheoloogia instituut (http:// dspace.ut.ee/handle/10062/48536 - 12. oktoober 2016).

Tamm, Marek 2000. Keha, pilt ja unenägu. Intervjuu Jean-Claude Schmittiga. Schmitt, Jean-Claude. Püha hurdakoer. Guinefort-lasteravitseja 13. sajandist. Tallinn: Varrak, lk 296-305.

Tamm, Marek 2014. Hiiglaste õlgadel. Tallinn: Eesti Keele Sihtasutus.

Tarkiainen, Kari \& Tarkiainen, Ülle 2014. Meretagune maa. Rootsi aeg Eestis 1561-1710. Tallinn: Varrak.

Tarkiainen, Ülle 2006. Talukõlvikud Vooremaal 17.-19. sajandil. Tannberg, Tõnu (koost). Vene aeg Eestis. Uurimusi 16. sajandi keskpaigast kuni 20. sajandi alguseni. Eesti Ajalooarhiivi toimetised 14 (21). Tartu: Eesti Ajalooarhiiv, lk 229-255.

Tarkiainen, Ülle 2009. Maamõõtjad Läänemere provintsides suure reduktsiooni ajal. Küng, Enn (toim). Läänemere provintside arenguperspektiivid Rootsi suurriigis 16/17. sajandil. Eesti Ajalooarhiivi toimetised 17 (24). Tartu: Eesti Ajalooarhiiv, lk 315-360.

Tarkiainen, Ülle 2010. Talude pärimine Eesti agraarühiskonnas 19. sajandi lõpul ja 20. sajandi alguses. Tannberg, Tõnu \& Woodworth, Bradley (koost). Vene impeerium ja Baltikum: venestus, rahvuslus ja moderniseerimine 19. sajandi teisel poolel ja 20. sajandi alguses. II. Eesti Ajalooarhiivi toimetised 18 (25). Tartu: Eesti Ajalooarhiivi Kirjastus, lk 255-282.

Tarkiainen, Ülle 2011. Maavalduste piirid ja piiritähised 13.-19. sajandil. Tuna. Ajalookultuuri Ajakiri 3, lk 17-33 (http://www.arhiiv.ee/public/TUNA/Artiklid/2011/ Tuna_2011_3.pdf - 12. oktoober 2016).

Tarkiainen, Ülle 2012a. Trees for marking boundaries of landed property in premodern Estonia. Estonian Journal of Ecology 61 (1), lk 51-63 (doi: 10.3176/eco.2012.1.06).

Tarkiainen, Ülle 2012b. Varaühisus või varaühendus? Abikaasade varalised suhted ja naiste maaomand Järvamaal 19. sajandi lõpul ja 20. sajandi alguses. Tannberg, Tõnu (koost). Eesti ajaloost 19.-20. sajandil. Uurimusi historiograafiast, allikaõpetusest ja institutsioonidest. Eesti Ajalooarhiivi toimetised 19 (26). Tartu: Eesti Ajalooarhiiv, lk 115-145. 
Tarkiainen, Ülle 2016. Vaestehoolekanne Liivimaa põhjaosa külaühiskonnas 19. sajandi teisel poolel. Ajalooline Ajakiri 2 (156), lk 215-244 (https://ojs.utlib.ee/index.php/EAA/ article/viewFile/AA.2016.2.04/8105 - 12. oktoober 2016).

Tarvel, Enn 1983. Lahemaa ajalugu. Tallinn: Eesti Raamat.

Traat, August 1980. Vallakohus Eestis 18. sajandi keskpaigast kuni 1866. aasta reformini. Tallinn: Eesti Raamat.

Viires, Ants 1975. Puud ja inimesed. Puude osast eesti rahvuskultuuris. Tallinn: Valgus.

\section{Summary}

\section{Possibilities for using folklore in studying peasant history}

\section{Ülle Tarkiainen}

Keywords: agrarian history, microhistory, narrating the past, oral history, settlement history

The possibilities for using folklore in studying history are directly dependent on the raised problem. In memories about the distant past, reality and fiction are often mixed up, which is why historians may regard the reliability of such stories as low. Still, such folklore shows what was valued, which events were felt to be significant and important. For historians, problems have been posed by the reliability and difficulties in dating the lore. In connection with the emergence of microhistory, more and more attention is being paid to how and what people thought, and it is often very difficult to find answers to this question in written sources.

This article observes the possibilities for using historical tradition in the studies of agrarian and settlement history and, more specifically, five narrow topics that concern border markers, the emergence of villages, land use in farms, inheritance matters, and beggars. Oral tradition about the founding of villages and farms and their first settlers is in most cases connected with the periods of war and the plague, immigration of people, or some other extraordinary event. Descriptions of everyday life, which are abundantly found in folk memory, usually speak about well known and familiar things. At the same time, they considerably help to broaden notions of the past and enable to find out the peasants' attitudes towards and evaluations of one or another event or phenomenon. As a result of taking folklore into consideration, the picture of history becomes much more differentiated and colourful.

The folklore that has been observed in this article is closely connected with the village society, and it primarily reveals notions connected with the farm people's everyday life. Archive sources usually disclose them from quite a different point of view. As a result of the analysis, we have reached the conclusion that the best results are achieved when historical tradition is taken into account for relatively recent events, those that have happened since the second half of the 19th century, and under circumstances in which spatial relationships have not considerably changed. The use of earlier lore is more 
complicated, although it also enables us to see people's attitudes, which gives a 'soul' to the discussed phenomena. The biggest difference is that archive materials, naturally, do not reflect the reasons hidden in the peasants' mental world. Namely, this is why the use of folklore enables to provide important extra material for studying settlement and agrarian history, which supplements a rational picture about past events and processes, and enables to open up deeper backgrounds to what happened. 